\title{
Women Participation in Environmental Protection and Management: Lessons from Plateau State, Nigeria
}

\author{
Solomon Z.Wuyep ${ }^{1, *}$, Vincent C.Dung ${ }^{1}$, Arin H.Buhari ${ }^{1}$, Daloeng H. Madaki ${ }^{1}$, Baminda A. Bitrus ${ }^{2}$ \\ ${ }^{1}$ Department of Geography, Plateau State University Bokkos, Nigeria \\ ${ }^{2}$ Department of Geography, Gombe State University Gombe, Nigeria \\ *Corresponding author: wuyepsol@yahoo.com
}

Received December 19, 2013; Revised March 07, 2014; Accepted March 12, 2014

\begin{abstract}
This study provides a general review and a case study of women's involvement in environmental management in Plateau state. Primary data were generated from Questionnaire survey of women from six local government areas. Majority of the women (79.2\%) are involved in farming and contributed significantly to land/soil conservation. (78.4\%) of them have planted tree or flowers in the last five years while (79.2\%) indicated clearing their surroundings daily in terms of sweeping, clearing drainages and refuse disposal. Problems faced by the women include lack of waste disposal equipment, poor drainage systems and lack of awareness among the general public. Appropriate recommendations were proffered to enhance women involvement in environmental protection and management.
\end{abstract}

Keywords: environmental, degradation, conservation, disposal, women

Cite This Article: Solomon Z.Wuyep, Vincent C.Dung, Arin H.Buhari, Daloeng H. Madaki, and Baminda A. Bitrus, "Women Participation in Environmental Protection and Management: Lessons from Plateau State, Nigeria.” American Journal of Environmental Protection, vol. 2, no. 2 (2014): 32-36. doi: 10.12691/env-2-2-1

\section{Introduction}

A lot of studies on women and environment have shown that women are significant actors in natural resources management and they are major contributors to environment rehabilitation and conservation. In addressing some key environmental problems women play a major role. Women through their roles as farmers and as collectors of water and firewood have a close connection with their local environment and often suffer most directly from environmental problems.

Women direct contact with environment has produced their deep-knowledge about the environment. Thus, women have served as agriculturalists, water resources managers and traditional scientists among others. Women are not only Knowledgeable about the environment, they are also protective and caring (shettima, 1996).Women being primarily responsible for domestic and household management interact more intensively with both the natural and built environment more than men. Consequently, they are more likely to suffer from a degraded home, neighborhood and city environment and to shoulder more of the burden that go with living in poor housing and communities with inadequate residential and health infrastructure since they spend more time at home and its immediate vicinity (Etta, 1999).

Governments the world over are new seeing the global dimension of a number of environment problems, such as climate change, ozone depletion, dumping of hazardous wastes, destruction of biological resources and of forests and the impact of desertification (Tolba,1992) therefore, the need to protect the environment became imperative.

Women have recorded successes in solving environmental problems all over the world. In India, the women realized that degradation of productive land has led to the erosion of top soil; the choking of water drainage was causing salinity and loss of food crops. They collectively leased degraded land and revived them through traditional farming. In three years 700 acres of land were restored to productive use (Ress,1992) they are more concerned about environmental protection and ecological preservation.

A lot has said about women activities and environmental improvement and protection. Moser (1991) Distinguishes between three roles for women

i) As managers or maintainers of the natural environment.

ii) Rehabilitators of the natural environment in the sense of sustainable development.

iii) As innovators in the use of appropriate technology in the creation of new environments.

Dankelman and Davidson (1998) observed that women play a major role in managing their natural surroundings and adopt several mechanisms to deal with the kinds of environmental crisis they face. They however, observed that the response of government have not been significant and as a result women, men and children continue to face problems including pollution, poor services, human waste pollution, fumes from household fuel and the consequences of soil erosion and flooding.

As rightly noted by Sayoe (1991) without the enhanced perception of a gendered analysis to guide into future 
environmental management programmes, a crash is inevitable. Therefore, there is the need to understand the various ways women have actively participated in environmental protection and management with a view to integrate them into environmental management programme. The objectives of this paper is to appraise women involvement in environmental management with particular reference to Plateau State, Nigeria.

\section{Study Area and Methods}

Plateau State lies in the central part of Nigeria between latitude $8^{0} 50^{1} \mathrm{~N}$ and $10^{\circ} 10^{\mathrm{I}} \mathrm{N}$ and longitude $8^{0} 22^{1} \mathrm{E}$ and $9^{0} 30^{1} \mathrm{E}$. The state shares boundaries with Bauchi state in the north, Taraba state in its eastern boundary, in the south by Nassarawa state and Kaduna state to the west. Jos North, Jos-south, Bokkos, Mangu are all located on the jos plateau where it is very hilly and in some cases mountainous. Slopes are mostly steep to very steep in nature.Vegetation is grass-land and is montane in nature. While Shendam and Langtang South belong to part of the adjoining Lowlands of the Jos Plateau. Slopes here are gentle to very gentle slopes.vegetation here is woodland savannah.

This paper makes used of two types of data. The first is the secondary source materials obtained from past studies of women involvement on environmental protection and management e.g from books and journal publications, and also articles from the internet. The second is from primary sources e.g through the administration of questionnaires to 125 women from rural areas in Plateau state, Nigeria. Six local government areas in Plateau state were purposively selected for the survey and women in these selected local government areas were subsequently selected randomely. The number of questionnaires administered to each of the Local Government Areas was based on the population of the Local Government. These local Government areas includes; Jos-North, Jos-south, Mangu, Bokkos, Langtang-South and Shendam. The respondents were randomly selected from the various wards and settlements in the study area. The data were analyzed using percentages.

\section{A Review of the Role of Women in Environmental Management and Protection.}

\subsection{Women in Agricultural and Soil Conservation}

All over the world, women contributed to agricultural production. They produce more than half of all the food that is grown (FAO, 1996). In sub-Sahara African and the Caribbean, women produce $80 \%$ of basic food stuffs, in Asia they provide fifty to ninety percent of the labour force for rice cultivation and $60 \%$ are involved in farming in Adamawa State Nigeria as reported by Adebayo et al (2005). Women roles in agriculture as listed by Levingo (1987) include; production and distribution, planting and cultivation, weeding, hoeing, harvesting and storage.

Women in Imo state of Nigeria, Gurei district of Adamawa State and women in (Yola North and South
Local Government Areas) contribute to food production (Ohuegbe as cited by Saito and Spurling, 1992 Adebayo 1998). These women apart from growing crops also engage in livestock production (e.g. sheep, goat and poultry) we can see that women interact closely with the environment (land in particular). As victims of soil degradation, women have participated actively in soil conservation projects. Example is the project Agroforestia in Yatenga, Burkina Faso. Igbo women now undertake some of the conventional male agricultural tasks in addition to those in the female domain (Ezumah and Domenico, 1995).

\subsection{Women in Forest Management and Tree Planting}

The need to protect biological diversity (forest) has been realized. This is because forests play a vital role in protecting the soils, water sheds and climatic stability. They are also rich sources of products-ranging from fruits, pharmaceuticals and latex to timber. Apart from that, Tolba (1992) rightly noted that loss of the species and the forests is something that cannot come back again, extinction is forever, whereas water pollution, air pollution, ozone depletion and desertification could all be controlled or minimized. Unfortunately, the main sources of energy (cooking fuel) for women are from natural resources viz; charcool, firewood and kerosene, intensive use of which can lead to deforestation, soil degradation and air pollution. Only very few rich women use gas or electric cookers. The interesting part of the whole dilemma is that we have greater women participation in forest management through tree planting, rehabilitation or protection.

Similarly, in Kenya, soil degradation and deforestation have created an acute shortage of wood, the women major source of energy. Thus, a green Belt movement of Kenya was formed, it planted over 7 million trees in 10years and set up over 1000 tree nurseries to the extent that it harvested fuel wood from its own trees and the fruit trees are bearing fruits. In addition, women participated in providing seedlings in nursery and flowers to beauty the environment (Maye, 1994). It is now very clear that women globally are playing a key role in the protection of the environment.

As rightly pointed out by Maye (1994), women worldwide are part of a growing movement for the protection of the living world, environment health and security, justice and the alleviation of poverty. Women play a major part in the protection of biological diversity through their many roles and responsibilities. One of the ways of protecting the environment and reducing hazard such as wind storms is by planting trees. As revealed by Adebayo et al 2001, that $70 \%$ of women in Adamawa state, Nigeria have planted trees in the last five years in their compounds $21 \%$ planted trees on their farms.

\subsection{Water Resources Management}

Women are always at the centre of the management of the communal water resources and house hold water requirement a survey conducted by Etta (1999) at Maroko Lower - income settlement in Lagos confirmed that the communal level, women are always in charge of the control and management of communal tap or water points. 
At times, they lock up the taps to prevent children from damaging the water pipes. At the household level, the burden of fetching water for cooking washing e.t.c falls on the women and girls. While men control the water trade. Where women do not have access to the tap water, they make use of streams rain water, well, rivers. e.t.c. At times, women also suffer from water pollution from untreated sewage which has a lot of health hazard (uyanga and Buteyo, 1999 Etta, 1999; mascarenhas, 1999).

Women provide water for their various domestic activities in rural area and the search for and carriage of water is solely women responsibility. To procure water for their various domestic activities, rural women do treck several Kilometers of distance. The mode and habit of obtaining the water performed in the river bank pollute the water (olanrewaju et al 2007)

\subsection{Solid Waste Disposal}

This present many challenges, particularly in the large cities whereby the amount of solid waste are increasing faster that the growth of population. Solid wastes are dumped at dumping site or undeveloped land. (Uyanga and Buteyo, 1999). Women because they are closer to the environment, engage in environmental management by cleaning the environment and keeping it clean especially in terms of garbage disposal. Giving the health hazard of garbage, women see to its regular disposal at the community level by doing it themselves.

\subsection{Drainage Management}

Women's involvement with environmental management and problems make them to participate actively in keeping drainages around them clean and free from trash and sand. According to Kwagala (1999) in his study in Kampala, Uganda. Drains are mainly cleaned by the women on a regular basis or pay to have them clean.

\section{Lesson from Plateau State, Nigeria}

This section discusses the results of the questionnaire survey of women's participation in environmental management in plateau state. The age and marital status of the women is shown in Table 2. Only $13.6 \%$ of the women surveyed are below the age of 20 years. Majority of the women $72.8 \%$ are in their middle ages (20-49 years) while only $13.6 \%$ are above 50 years. The implication of this age distribution is that most of the women are still in their prime ages and hence energetic to take active part in environmental management activities.

Table 1. THE SPREAD OF RESPONDANCE

\begin{tabular}{|c|c|c|}
\hline Local Government Area & No. of Women selected & Percentage \\
\hline Jos- North & 30 & 24 \\
\hline Jos-South & 25 & 20 \\
\hline Bokkos & 15 & 12 \\
\hline Mangu & 20 & 16 \\
\hline Shendam & 23 & 18.4 \\
\hline Lantang-South & 12 & 9.6 \\
\hline Total & 125 & 100 \\
\hline
\end{tabular}

SOURCE: Field Survey, 2013.

Table 2. Age and marital status of surveyed women

\begin{tabular}{|c|c|c|}
\hline Age Group & Number & Percentage \\
\hline Less than 20 years & 17 & 13.6 \\
\hline 20-29 years & 30 & 24.0 \\
\hline 30-39 years & 21 & 16.8 \\
\hline 40-49years & 40 & 32.0 \\
\hline 50 -59 years & 17 & 13.6 \\
\hline 60 years and above & - & - \\
\hline & 125 & 100 \\
\hline Marital Status & Number & Percentage \\
\hline Married & 96 & 76.8 \\
\hline Single & 29 & 23.2 \\
\hline
\end{tabular}

SOURCE: Field Survey, 2013.

Marital Status indicates that $76.8 \%$ of the women are married while only $23.2 \%$ are single. This high proportion of married women in the study area suggest that they are likely to be more responsible in protecting and keeping the environment clean because of their roles as home keepers.

From Table 3, majority of the women in all the local government areas have atleast attended secondary education. By implication, most of the women in the study area are well informed about environmental protection.

Table 3. Educational Qualification of Respondance

\begin{tabular}{|c|c|c|c|c|c|c|c|c|c|c|c|c|}
\hline \multirow{2}{*}{$\begin{array}{l}\text { LOCATION } \\
\text { Qualification }\end{array}$} & \multicolumn{2}{|c|}{ JOS NORTH } & \multicolumn{2}{|c|}{ JOS SOUTH } & \multicolumn{2}{|c|}{ BOKKOS } & \multicolumn{2}{|c|}{ MANGU } & \multicolumn{2}{|c|}{ LANGTANG SOUTH } & \multicolumn{2}{|c|}{ SHENDAM } \\
\hline & Freq. & $\%$ & Freq & $\%$ & Freq & $\%$ & Freq & $\%$ & Freq & $\%$ & Freq & $\%$ \\
\hline Primary & 10 & 33.3 & 6 & 24 & 2 & 13.3 & 4 & 20 & 3 & 25.0 & 6 & 26.1 \\
\hline Secondary & 12 & 40.0 & 10 & 40 & 8 & 53.3 & 9 & 45 & 5 & 41.7 & 17 & 73.9 \\
\hline Tertiary & 3 & 10.0 & 4 & 16 & 2 & 12.3 & 4 & 20 & 3 & 25.0 & 0 & 0 \\
\hline Non Formal education & 5 & 16.7 & 5 & 20 & 3 & 20.0 & 3 & 15 & 1 & 8.3 & 0 & 0 \\
\hline TOTAL & 30 & 100 & 25 & 100 & 15 & 100 & 20 & 100 & 12 & 100 & 23 & 100 \\
\hline
\end{tabular}

SOURCE: Field Survey, 2013

Majority of the women surveyed $79.2 \%$ are involved in farming (Table 4). This confirms from other studies that women participate greatly in food production especially in developing countries(Etta, 1999; shettima, 1996). As earlier established in the review, women contribute significantly to land/soil conservation. In the study area the commonest method employed by the women in soil conservation is mulching. One of the ways of protecting the environment and reducing hazard such as wind storms and erosion is by planting trees. In the study area, the survey revealed that almost $78.4 \%$ of the women have planted trees or flowers in the last five years. This again buttressed the previous findings that women are actively involved in tree planting. When asked where the tree or flowers were planted, $44.8 \%$ indicated their compounds, $22.4 \%$ planted trees on the farm while $32.8 \%$ planted theirs in other places. Fruit trees (e.g Mango, Citrus etc.) constitute the bulk of the trees planted by majority of the women. This is done with the twofold objectives of protecting the environment and also providing fruits for the household. 
Table 4. women involvement in environmental management

\begin{tabular}{|c|c|c|}
\hline Involvement In Farming & Number & Percentage \\
\hline Yes & 99 & 79.2 \\
\hline No & 26 & 20.8 \\
\hline Conservation methods being used & Number & Percentage \\
\hline Mulching & 72 & 57.6 \\
\hline Planting across the slope & 28 & 22.4 \\
\hline Terracing & 25 & 20 \\
\hline Planted trees in the last 5 years & Number & Percentage \\
\hline Yes & 98 & 78.4 \\
\hline No & 27 & 21.6 \\
\hline Where planted & Number & Percentage \\
\hline On the farm & 28 & 22.4 \\
\hline Around the compound & 56 & 44.8 \\
\hline Others & 41 & 32.8 \\
\hline Species planted & Number & Percentage \\
\hline Fruit trees & 79 & 63.2 \\
\hline Flowers & 21 & 16.8 \\
\hline Other tree species & 25 & 20.0 \\
\hline Frequency of cleaning the environment & Number & Percentage \\
\hline Daily & 99 & 79.2 \\
\hline Weekly & 15 & 12.0 \\
\hline Occasionally & 11 & 8.8 \\
\hline Major activity in environmental Cleaning & Number & Percentage \\
\hline Weeding & 40 & 32.0 \\
\hline Sweeping & 72 & 57.6 \\
\hline Cleaning drainage & 12 & 9.6 \\
\hline Others & 01 & 0.8 \\
\hline
\end{tabular}

Women are main actors in environmental sanitation at homes and communities. About $79.2 \%$ of the women survey indicated that they clear their surroundings daily, $12.0 \%$ do it weekly while $8.8 \%$ do it occasionally.

When asked the major activity they perform in cleaning the environment, majority $57.6 \%$ indicated sweeping. This is followed by weeding $32.0 \%$ and clearing of drainage $9.6 \%$ other activities such as packing refuse, filing ditches e.tc constitutes $0.8 \%$.

The respondents listed the following as the problems confronting women in environmental management in the study area.

1. Lack of environmental awareness among the general public

2. Lack of waste disposal equipment

3. Poor drainage systems

\section{Recommendations}

To enhance women participation in environmental management for sustainable development the following recommendations are proffered, given the challenges facing the women.

Isolation of women from decision making on environment has made their views not being hard and they could not influence decision making process with affect the environment they interact with. Thus, women should be encouraged to participate in committees on environmental protection, programmes and policies to address gender imbalances in decision making. Women access to land and other resources should be ensured and not undermined. The government will have to come in to ensure gender equity in regards access to and control of resources.
Environmental education is required for the generality of Nigerians for sustainable development. Many people litter the streets with pieces of paper, Oranges or banana peels, can plastics and polythene bags just for the fun of it. Environmental education will produce changes in attitude of the public as well as impart specific knowledge on the generality of Nigerians.

Incinerators should be placed at strategic places to be used by the public. Separation of plastics from municipal solid wastes and recycling of plastics will help to reduce the contribution of plastics to the solid waste problem as well as eliminate the unsightly littering. Biodegradable plastics' could also be used (pryde, 1973) these will eventually decompose.

Women education and access to education for girls should be seen as a policy priority. Educated women will contribute more significantly to bringing the gap between environment and development. Empowerment of women in sustainable human development and in relation to the protection of the environment must be recognized and sustained.

\section{Conclusion}

In conclusion, both married and single women where involved in environmental protection. However, the bulk of the women involved in environmental protection are married women ( $76.8 \%$ of them). This high proportion of married women in the study area suggest that they are likely to be more responsible in protecting and keeping the environment clean because of their roles as home keepers.

Thus, this paper has discussed the various ways women have participated actively in environmental protection and natural resources management in order to ensure sustainable use of environmental resources. Recommendations are proffered especially those that can help the goal of women empowerment the critical role of women as resource manager, as community activists as environmental advocates must be recognized when strategies for the protection of environment are being developed.

Women should be allowed to participate at the local, regional, national and international levels on environmental issues. In the words of Maye, (1994) for this participation to be meaningful, should go beyong tokenism. To make a significant impact on decision making, women should be present in equal numbers to men (or at least on a 40: 60 proportional split of genders). As resource managers, women should be consulted and supported in what they are already doing to protect the environment specifically, more women should be involved in decision making with regards to policies, programmes or funding of environment.

\section{References}

[1] Adebayo. A. A and Anyanwu. S. O (2005). Women participation in Environmental protection and management: Lesson from Adamawa, Nigeria paraclete.

[2] Dankelman. I and Davidson, J (1997) women and environment in the third world Landon; Earthscan publication.

[3] Etta, F.E (1999). Maroko low- income settlemet in Lagos, Nigeria; Gender and Urban Natral resources management in D. L. smith women managing resources Mazigira institute, Nairobi. 
[4] Ezumah W. N and Di Domenico, C.M (1995). Enhancing the role of women in crop prodvction; a case study of Igbo women in Nigeria world Development 23 (10), p 1731-1744.

[5] Kwagala, B(1999). Katwogo and Kawala Low- income Urban settlements in kampala, Uganda; Gender and the management of Urban Environmental Health on D. L. smith, women managing resources. Mazingira institute, Nairobi.

[6] Maye. A, (1994). Women: the Resource manager UNEP, Vol 6. No4, pp. 23-24.

[7] Olanrenwaju. R.M and Ogunleye C.I (2007) women in environmental Degradation Environmental Journal VII.
[8] Pryde, F. (1973) Environmental Chemistry; An Introduction. Cummings publishing campany. Inc. Phillippines.

[9] Ress, P. (1992). Women success in Environment Management, UNEP, Our Planet, Vol. 4. No 1. PP 16-18.

[10] Shettima, A. G (1996). Gender issues in monitoring the environment: The case of Rural Nigeria. A paper presented at the $39^{\text {th }}$ Annual conference of the Nigerian geographical Association, $5^{\text {th }}-8^{\text {th }}$ May, at university of Maiduguri.

[11] Tolba, M. (1992), changes for past two decades and the prospect for the future. UNEP, our planet Vol. 4, No. 6, pp 8-11. 